\title{
Article \\ A Toxic Synergy between Aluminium and Amyloid Beta in Yeast
}

\author{
Jamieson B. Mcdonald, Sudip Dhakal (D) and Ian Macreadie *(D)
}

Citation: Mcdonald, J.B.; Dhakal, S.; Macreadie, I. A Toxic Synergy between Aluminium and Amyloid Beta in Yeast. Int. J. Mol. Sci. 2021, 22, 1835. https://doi.org/10.3390/ijms 22041835

Academic Editor: Sang Won Suh

Received: 23 December 2020

Accepted: 8 February 2021

Published: 12 February 2021

Publisher's Note: MDPI stays neutral with regard to jurisdictional claims in published maps and institutional affiliations.

Copyright: (c) 2021 by the authors. Licensee MDPI, Basel, Switzerland. This article is an open access article distributed under the terms and conditions of the Creative Commons Attribution (CC BY) license (https:/ / creativecommons.org/licenses/by/ $4.0 /)$.
School of Science, RMIT University, Bundoora, VIC 3083, Australia; s3689785@student.rmit.edu.au (J.B.M.); sudip.dhakal@rmit.edu.au (S.D.)

* Correspondence: ian.macreadie@rmit.edu.au; Tel.: +61-399-256-627

\begin{abstract}
Alzheimer's disease (AD), the most prevalent, age-related, neurodegenerative disease, is associated with the accumulation of amyloid beta $(\mathrm{A} \beta)$ and oxidative stress. However, the sporadic nature of late-onset $\mathrm{AD}$ has suggested that other factors, such as aluminium may be involved. Aluminium $\left(\mathrm{Al}^{3+}\right)$ is the most ubiquitous neurotoxic metal on earth, extensively bioavailable to humans. Despite this, the link between $\mathrm{Al}^{3+}$ and $\mathrm{AD}$ has been debated for decades and remains controversial. Using Saccharomyces cerevisiae as a model organism expressing A $\beta 42$, this study aimed to examine the mechanisms of $\mathrm{Al}^{3+}$ toxicity and its interactions with $\mathrm{A} \beta 42$. S. cerevisiae cells producing $\mathrm{A} \beta 42$ treated with varying concentrations of $\mathrm{Al}^{3+}$ were examined for cell viability, growth inhibition, and production of reactive oxygen species (ROS). $\mathrm{Al}^{3+}$ caused a significant reduction in cell viability: cell death in yeast producing green fluorescent protein tagged with A $\beta 42$ (GFP-A $\beta 42)$ was significantly higher than in cells producing green fluorescent protein (GFP) alone. Additionally, $\mathrm{Al}^{3+}$ greatly inhibited the fermentative growth of yeast producing GFP-A $\beta 42$, which was enhanced by ferric iron $\left(\mathrm{Fe}^{3+}\right)$, while there was negligible growth inhibition of GFP cells. $\mathrm{Al}^{3+}$ - induced ROS levels in yeast expressing native $A \beta 42$ were significantly higher than in empty vector controls. These findings demonstrate $\mathrm{Al}^{3+}$ has a direct, detrimental toxic synergy with $\mathrm{A} \beta 42$ that can be influenced by $\mathrm{Fe}^{3+}$, causing increased oxidative stress. Thus, $\mathrm{Al}^{3+}$ should be considered as an important factor, alongside the known characteristic hallmarks of $\mathrm{AD}$, in the development and aetiology of the disease.
\end{abstract}

Keywords: aluminium; amyloid beta; Alzheimer's disease; iron; Fenton chemistry; oxidative stress; yeast

\section{Introduction}

Aluminium is the most plentiful neurotoxic metal on earth and is extensively bioavailable to humans [1]. Aluminium is widely found in consumer products (e.g., antacids, deodorants, foods, water, and beverages) and has been used for industrial applications and in manufacturing (e.g., glasses, alum, and clays) for centuries [1,2]. Aluminium's free ion, $\mathrm{Al}^{3+}$ is widely recognized as a neurotoxin that disrupts more than 200 biological functions and causes several adverse effects in yeast, plants, animals, and humans [2]. Studies have shown that a high daily intake of aluminium is associated with elevated risks of dementia or cognitive impairment [3]. The chemical properties of $\mathrm{Al}^{3+}$ including its small ionic radius and high charge play important roles by which the metal ion exerts its neurotoxicity [1]. The ability of $\mathrm{Al}^{3+}$ to cross the blood-brain barrier (BBB) facilitates its implications with various damages to the nervous system, and it has been repeatedly demonstrated to accumulate in neuronal cells susceptible to $\mathrm{AD}[1,2,4] . \mathrm{Al}^{3+}$ neurotoxicity and potential contribution to $\mathrm{AD}$ is mediated through its promotion of amyloid aggregation and accumulation, reactive oxygen species (ROS) production, oxidative stress, lipid peroxidation, and apoptosis [1,2]. Furthermore, $\mathrm{Al}^{3+}$ disrupts biometal ion homeostasis, replacing essential biometals in numerous enzymatic reactions [1]. Additionally, $\mathrm{Al}^{3+}$ transport and uptake are influenced by biometal ions, such as iron. $\mathrm{Al}^{3+}$ has been shown to compete with iron via its binding to iron transporters, lactoferrin (Lf)/lactoferrin receptor (LfR) or transferrin (Tf)/transferrin 
receptor (TfR), facilitating $\mathrm{Al}^{3+}$ transport across the BBB [1,5]. Specifically, brain uptake of $\mathrm{Al}^{3+}$ occurs via transferrin-receptor-mediated endocytosis, diffusion, and carrier-mediated transporters.

$\mathrm{Al}^{3+}$ accumulation in human brain tissues represents a critical factor of ageing, leading to oxidative damage and disruption of signalling cascades resulting in neuronal death. $\mathrm{Al}^{3+}$ accumulates at high concentrations in regions of the brain such as the entorhinal cortex and the hippocampus [1,4]. Pyramidal cells, basal forebrain cholinergic neurons, and catecholaminergic neurons are particularly susceptible to aluminium-induced neurofibrillary degeneration [1]. These parts of the brain are highly susceptible to AD at exceedingly early stages of its pathological development [1,4]. Miniscule quantities of $\mathrm{Al}^{3+}$ are required to produce neurotoxicity, which can occur via dietary $\mathrm{Al}^{3+}$ intake [1]. Incremental exposure to small amounts of $\mathrm{Al}^{3+}$ over a lifetime supports its selective build-up in regions of the brain [1]. Furthermore, there are several intraneuronal pools including citrate, ATP, glutamic acid, and nucleic acids, where aluminium could exist in a benign state and accumulate over time before the reactive form of aluminium, $\mathrm{Al}^{3+}$, surpasses a serious threshold and starts to exert toxicity [6].

Evidence has consistently shown that long-term exposure to $\mathrm{Al}^{3+}$ results in neuropathological hallmarks of $\mathrm{AD}$ (Figure 1) [1,2,4,7-9]. Despite this, the role of $\mathrm{Al}^{3+}$ in $\mathrm{AD}$ has been strongly disputed for decades and remains controversial $[1,2,7]$. The continued debate and criticism regarding the role of $\mathrm{Al}^{3+}$ in $\mathrm{AD}$ and other neurodegenerative diseases also stems from the complex characteristics of $\mathrm{Al}^{3+}$ bioavailability making it challenging to assess its toxicity and, hence, a direct relationship between $\mathrm{Al}^{3+}$ and $\mathrm{AD}$ is yet to be established. Currently there are no therapeutics prescribed for the prevention or alleviation of AD development even with 200 clinical trials in the past two decades searching for treatments. Therefore, more research is needed. Yeast presents itself as a powerful model organism to assess $\mathrm{Al}^{3+}$ toxicity.

The amyloid beta hypothesis [10] represents the leading explanation for AD pathogenesis; thus, there is extensive research to prevent $A \beta$-induced damage and the consequent death of neuronal cells [10]. It well recognized that an imbalance involving the assembly and clearance of $A \beta_{42}$ and related $A \beta$ peptides is an early, and often instigating, factor of $\mathrm{AD}$ [10]. The formation of $\mathrm{A} \beta_{42}$ assemblies including monomers, oligomers, and insoluble fibrillary polymers $[11,12]$ results in microglial activation, elevated oxidative stress, mitochondrial dysfunction, and synapse dysfunction and interferes with cellular communications, resulting in a cascade of disease and neuronal atrophy $[10,11,13]$. Although over-production of $A \beta$ peptides can occur very early in individuals who develop $A D$ and plays a key role in pathogenesis, it is not sufficient to cause the disease. Excessive production of $A \beta$ in some aged individuals does not lead to the development of cognitive impairment [14]. Thus, other factors such as oxidative stress, mitochondrial dysfunction, biometal dyshomeostasis, and potential toxic accumulations of metals such as $\mathrm{Al}^{3+}$ in the brain must be considered.

Saccharomyces cerevisiae has proven to be a facile model for studying AD, providing unprecedented insights into the underlying molecular basis of ageing and in deciphering the complexity of disease pathology involved in $\mathrm{AD}[13,15,16]$. We have developed yeast-based models for investigating the effects of compounds that alleviate the toxicity associated with $A \beta_{42}$ and those that synergistically increase $A \beta$ toxicity [17-19]. For example, the model system discussed above has been used to demonstrate a toxic synergy between tyramine and $A \beta 42$ via oxidative stress and mitochondrial dysfunction [19]. In this study, the yeast-based model system has been used to investigate cellular responses to $\mathrm{A} \beta 42$ and $\mathrm{Al}^{3+}$ by treating S. cerevisiae expressing GFP-A $\beta 42$ and GFP alone with varying concentrations of $\mathrm{Al}^{3+}$. The comparison between these two constructs can be made due to the growth of transformants under normal conditions being highly similar and robust [19]. Using a growth inhibition assay and viability measurements coupled with ROS analysis, this report demonstrates that the neurotoxic properties of $\mathrm{Al}^{3+}$ and $\mathrm{A} \beta 42$ are exacerbated 
by one another, causing an adverse synergistic effect on growth via increased oxidative damage. $\mathrm{Fe}^{3+}$ was found to influence the synergistic toxicity of $\mathrm{Al}^{3+}$ and $\mathrm{A} \beta 42$.

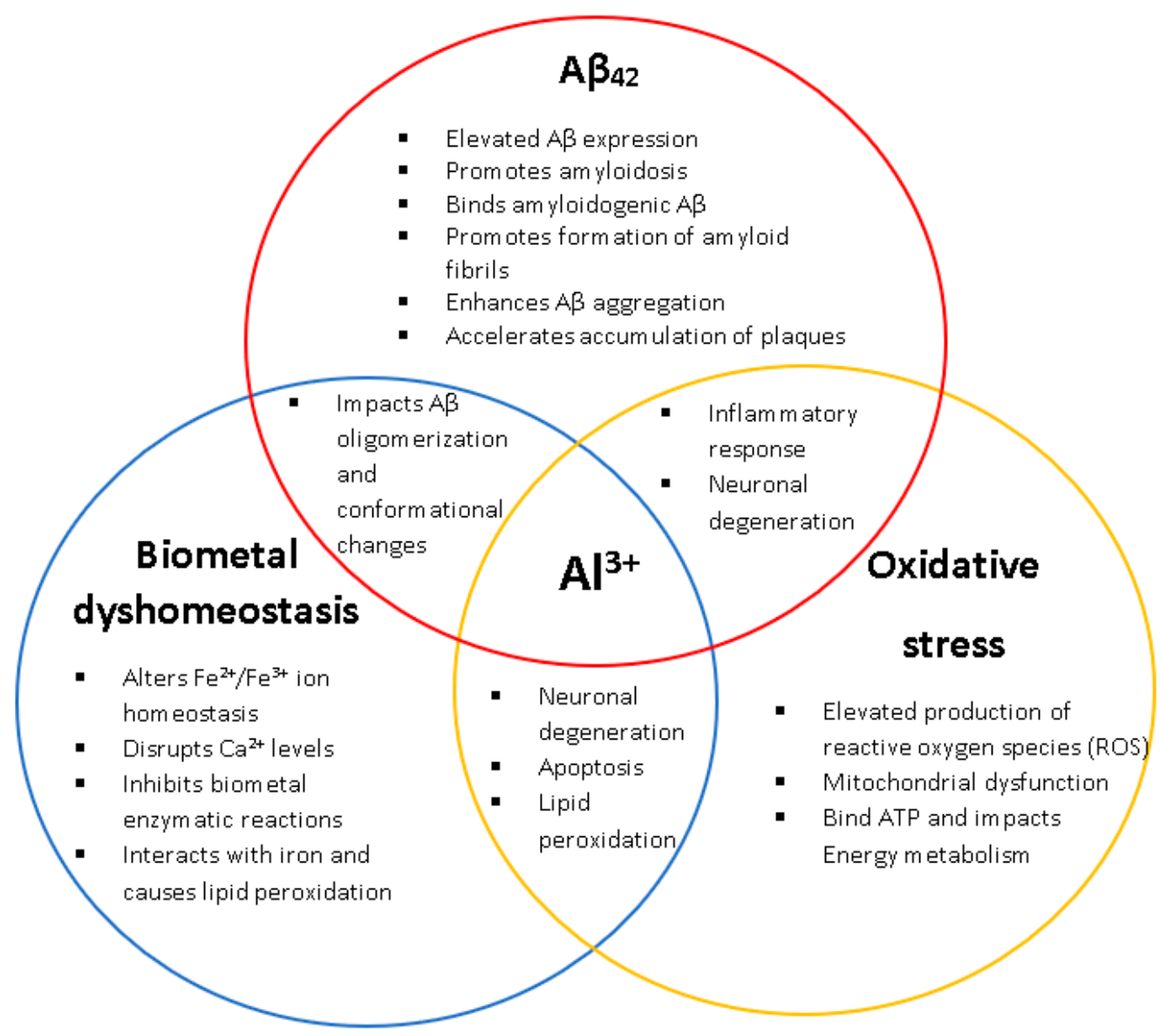

Figure 1. The biological relationships and impacts $\mathrm{Al}^{3+}$ has on the characteristic hallmarks of Alzheimer's disease (AD) (amyloid beta, biometal dyshomeostasis, and oxidative stress). $\mathrm{Al}^{3+}$ has been experimentally shown to induce all key pathological events associated with $\mathrm{AD}$, at multiple levels.

\section{Results}

2.1. Aluminium Is Cytotoxic, Inhibits the Growth of Yeast Cells, and Its Toxicity is Exacerbated by the Presence of $A \beta_{42}$

To investigate the cytotoxicity of $\mathrm{Al}^{3+}$ and whether it is enhanced by $\mathrm{A} \beta 42$, S. cerevisiae BY4743 [p416GPD.GFP] and BY4743 [p416GPD.GFPA $\beta$ ] transformants in the log phase of growth were suspended in water and treated with varying concentrations $(0,1.6,3.2$, 4.8 and $10 \mathrm{mM}$ ) of $\mathrm{Al}^{3+}$. On complete yeast extract peptone dextrose (YEPD) and yeast extract peptone ethanol (YEPE) media, transformants were shown to be extremely sensitive to $\mathrm{Al}^{3+}$, with the addition of $\mathrm{Al}^{3+}$ resulting in a significant diminishment of cell survival. Cell death was dependent on $\mathrm{Al}^{3+}$ concentration and the presence of $\mathrm{A} \beta_{42}$ (Figure 2). On YEPD medium, $\mathrm{Al}^{3+}$ concentrations as high as $4.8 \mathrm{mM}$ were not toxic towards cells under experimental conditions. However, $24 \mathrm{~h}$ of $\mathrm{Al}^{3+}$ exposure at concentrations of 10 $\mathrm{mM}$ resulted in a substantial reduction in cell viability both in cells producing GFP and in those producing GFP-A $\beta 42$. This result implies $\mathrm{Al}^{3+}$ is cytotoxic on its own. Cells exposed to $10 \mathrm{mM} \mathrm{Al}{ }^{3+}$ resulted in the death of $38 \%$ of the cell population producing GFP, and $\mathrm{Al}^{3+}$ exhibited much greater toxicity towards cells producing GFP-A $\beta_{42}$, killing $59 \%$ of the cell population (Figure 2). Thus, at $10 \mathrm{mM}, \mathrm{Al}^{3+}$ induced significantly greater $(20 \%)$ cell death in yeast producing GFP-A $\beta_{42}$ as compared to that in cells producing GFP 
(Figure 2). This result demonstrates that $\mathrm{Al}^{3+}$ cytotoxicity is enhanced by the presence of $\mathrm{A} \beta_{42}$. Thus, it can be concluded that an interactive toxic synergy between $\mathrm{Al}^{3+}$ and $\mathrm{A} \beta_{42}$ exists. However, significantly greater concentrations, e.g., $5-10 \mathrm{mM}$ of $\mathrm{Al}^{3+}$, were required to observe toxicity in yeast under the reported experimental conditions. Although these levels are much higher than those observed in human brains [20-23], we did not study actual aluminium uptake in yeast cells.

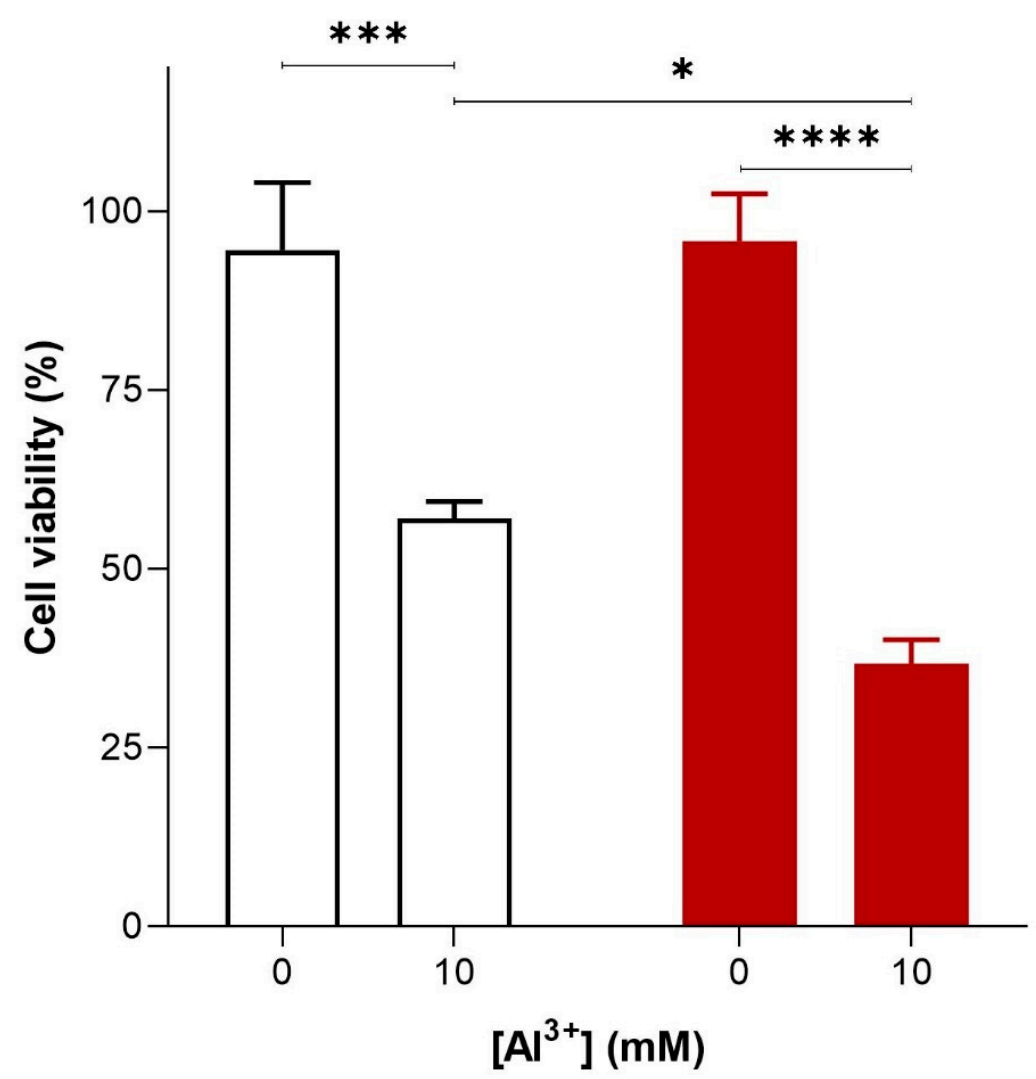

Figure 2. $\mathrm{Al}^{3+}$-mediated cell killing of Saccharomyces cerevisiae transformant strains BY4743 [p416GPD.GFP] (white bar) and BY4743 [p416GPD.GFPA $\beta$ ] (red bar). S. cerevisiae transformant strains BY4743 [p416GPD.GFP] and BY4743 [p416GPD.GFPA $\beta$ ] were suspended in water and treated with $10 \mathrm{mM} \mathrm{Al2(SO4)3.} \mathrm{After} 24 \mathrm{~h}$, cells were plated on yeast extract peptone dextrose (YEPD) and incubated for 4 days at $30^{\circ} \mathrm{C}$ to determine cell viability. Values are from triplicates; the mean and standard deviation are shown. Values significantly different from $0 \mathrm{mM} \mathrm{Al}^{3+}$ and between the two transformant strains in a two-way ANOVA with Tukey's post hoc analysis are indicated with asterisks: ${ }^{*} p<0.01,{ }^{* * *} p<0.0003,{ }^{* * * *} p<0.0001$.

Similar results (not shown) were obtained when cells were plated onto YEPE, indicating that the treatment did not induce petites (respiratory-deficient colonies) in yeast.

To provide further evidence that $\mathrm{Al}^{3+}$ and $\mathrm{A} \beta 42$ have a synergistic toxicity and are the potential cause of cell death observed, $\mathrm{Al}^{3+}$ toxicity was also examined using fermentative growth inhibition assays of the same cell populations described above; yeast cells constitutively expressing GFP-A $\beta 42$ or GFP alone. Low-pH and low-phosphate (LPP) medium was used to analyse the growth inhibitory effects of $\mathrm{Al}^{3+}$ and $\mathrm{A} \beta_{42}$ on yeast cells. On solidified LPP medium, $\mathrm{Al}^{3+}$ concentrations up to $1.6 \mathrm{mM}$ exerted no significant growth inhibition of transformant strains producing GFP-A 342 or GFP alone (Table 1). $\mathrm{Al}^{3+}$ concentrations of $3.2 \mathrm{mM}$ showed some reduction in growth towards both strains, and concentrations of 4.8 and $6.4 \mathrm{mM}$ severely inhibited the growth of cells producing GFP-A $\beta_{42}$. 
Table 1. Growth of S. cerevisiae transformants in the presence of varying concentrations of $\mathrm{Al}^{3+}$.

\begin{tabular}{|c|c|c|c|c|c|c|c|}
\hline \multirow{2}{*}{$\begin{array}{c}\text { Transformant Yeast } \\
\text { Strain }\end{array}$} & \multicolumn{7}{|c|}{3 Days } \\
\hline & $0 \mathrm{Al}$ & $0.4 \mathrm{Al}$ & $0.8 \mathrm{Al}$ & $1.6 \mathrm{Al}$ & $3.2 \mathrm{Al}$ & $4.8 \mathrm{Al}$ & $6.4 \mathrm{Al}$ \\
\hline \multirow{4}{*}{$\begin{array}{c}\text { BY4743 [p416GPD.GFP] } \\
\text { BY4743 } \\
\text { [p416GPD.GFP.A } \beta]\end{array}$} & +++ & +++ & +++ & +++ & ++ & ++ & + \\
\hline & ++ & ++ & ++ & + & + & + & - \\
\hline & \multicolumn{7}{|c|}{7 Days } \\
\hline & O Al & $0.4 \mathrm{Al}$ & $0.8 \mathrm{Al}$ & $1.6 \mathrm{Al}$ & $3.2 \mathrm{Al}$ & $4.8 \mathrm{Al}$ & $6.4 \mathrm{Al}$ \\
\hline BY4743 [p416GPD.GFP] & +++ & +++ & +++ & +++ & +++ & ++ & + \\
\hline $\begin{array}{c}\text { BY4743 } \\
\text { [p416GPD.GFP.A } \beta \text { ] }\end{array}$ & +++ & +++ & +++ & ++ & ++ & + & - \\
\hline
\end{tabular}

Yeast cells producing GFP showed little growth inhibition at $4.8 \mathrm{mM} \mathrm{Al}^{3+}$ compared to cells producing GFP-A $\beta$, and at $6.4 \mathrm{mM} \mathrm{Al}^{3+}$, no growth of GFP-A $\beta_{42}$ was observed (Figure 3). However, the control yeast transformant producing GFP alone showed much less growth inhibition at this level of $\mathrm{Al}^{3+}$. Thus, results indicate $\mathrm{Al}^{3+}$ has a greater inhibitory impact on the fermentative growth of cells expressing GFP-A $\beta_{42}$ compared to those producing GFP alone. $\mathrm{Al}^{3+}$ at these levels is lethal towards cells expressing $\mathrm{A} \beta_{42}$, coinciding with results obtained from cell viability/cytotoxicity measurements.

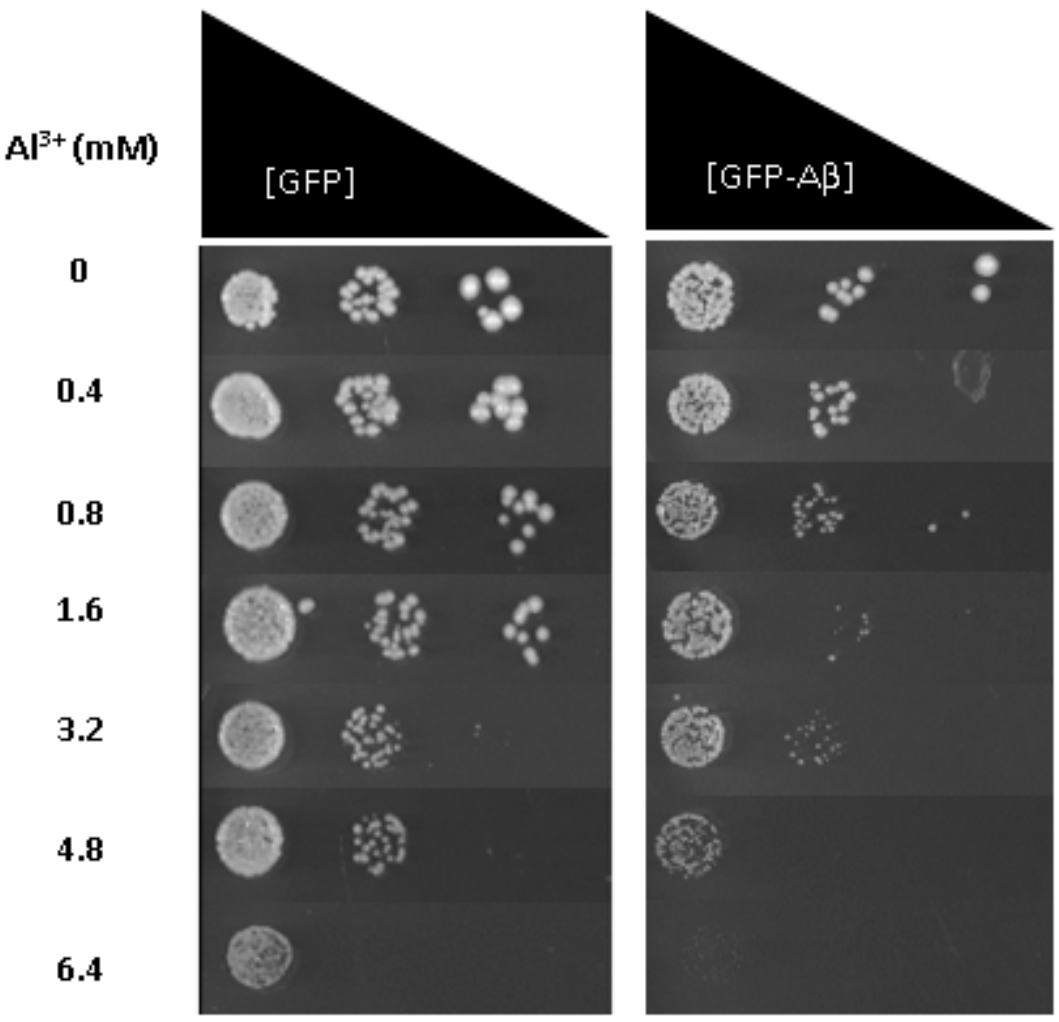

Figure 3. Growth of S. cerevisiae BY4743 [p416GPD.GFP] and BY4743 [p416GPD.GFPA $\beta$ ] transformants on low-pH and low-phosphate (LPP) medium containing varying concentrations of $\mathrm{Al}^{3+}$ incubated at $30{ }^{\circ} \mathrm{C}$ for 7 days. Analysis of growth inhibition was performed in triplicate rows (transformant strains) and compared. The difference in growth inhibition between the two transformants provides another line of evidence that the combination of $\mathrm{A} \beta 42$ and $\mathrm{Al}^{3+}$ has a synergistic toxicity towards cells, with $\mathrm{Al}^{3+}$ having a dose-dependent toxicity. 


\section{2. $\mathrm{Fe}^{3+}$ Increases $A l^{3+}$ Toxicity, and $A l^{3+}$ and $A \beta_{42}$ Toxic Synergy}

To ascertain whether $\mathrm{Fe}^{3+}$ exacerbates $\mathrm{Al}^{3+}$ synergistic toxicity with $\mathrm{A} \beta 42, \mathrm{Fe}^{3+}$ was added to LPP medium containing varying concentrations of $\mathrm{Al}^{3+}$, and the growth inhibition of yeast cells constitutively expressing GFP-A $\beta 42$ and GFP alone was examined. On solidified LPP medium, the addition of $2 \mathrm{mM} \mathrm{Fe}^{3+}$ to $\mathrm{Al}^{3+}$ concentrations as low as $1.6 \mathrm{mM}$ exerted growth inhibition of yeast strains producing GFP-A $\beta 42$ and GFP alone (Figure 4). The addition of $\mathrm{Fe}^{3+}$ inhibited the growth of yeast cells expressing GFP-A $\beta 42$ to a greater extent than cells expressing GFP alone; however, the difference was only subtle. This result suggests $\mathrm{Fe}^{3+}$ increases $\mathrm{Al}^{3+}$ and $\mathrm{A} \beta 42$ synergistic cytotoxicity. Both yeast strains exposed to $\mathrm{Al}^{3+}$ concentrations of 3.2 and $4.8 \mathrm{mM}$ in combination with $2 \mathrm{mM} \mathrm{Fe}^{3+}$ expressed severe growth inhibition, displaying almost no growth. Taken together, it is clear $\mathrm{Fe}^{3+}$ increases the toxic effects of $\mathrm{Al}^{3+}$ and also increases the toxic synergy between $\mathrm{Al}^{3+}$ and $\mathrm{A} \beta 42$. Results provide evidence that $\mathrm{Fe}^{3+}$ may play an important role in $\mathrm{Al}^{3+}$ toxicity towards neuronal cells and in the development of AD.

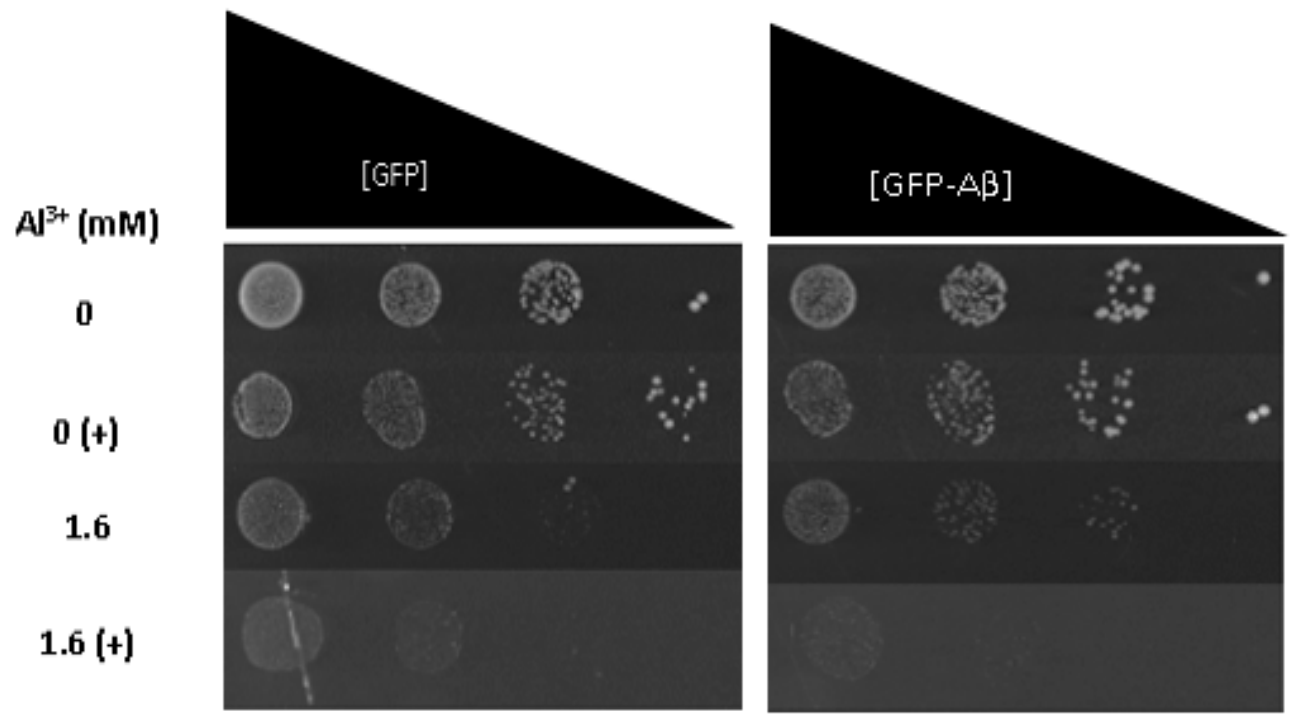

Figure 4. Growth of S. cerevisiae BY4743 [p416GPD.GFP] and BY4743 [p416GPD.GFP.A $\beta$ ] cells on LPP medium containing $1.6 \mathrm{mM}$ of $\mathrm{Al}^{3+}$ and $2 \mathrm{mM} \mathrm{Fe}^{3+}$ indicated by (+), plates were incubated at $30^{\circ} \mathrm{C}$ for 7 days.

\subsection{Aluminium Elevates ROS Levels in Yeast, Enhancing Oxidative Stress in Yeast Producing $A \beta_{42}$}

To verify whether $\mathrm{Al}^{3+}$ induces oxidative stress via elevated levels of intracellular ROS and whether ROS generation is enhanced by $A \beta 42$, flow cytometric analyses were used to quantify ROS-activated H2DCF-DA fluorescence in cells producing A $\beta 42$, BY4743 [pYEX.A $\beta$ ], and in empty vector control BY4743 [pYEX.BX] lacking A $\beta 42$. These strains were used instead of BY4743 [p416GPD.GFP] and BY4743 [p416GPD.GFP.A $\beta$ ] used in the previous experiments because plasmids [p416GPD.GFP] and [p416GPD.GFP.A $\beta$ ] contain GFP. Dichlorofluorescein (DCF) fluoresces at $530 \mathrm{~nm}$ when excited at $488 \mathrm{~nm}$, and green fluorescence is emitted; thus, the presence of GFP would interfere with DCF fluorescence analysis and ROS quantification. For this reason, yeast strains BY4743 [pYEX.A $\beta$ ] and BY4743 [pYEX.BX] were used for ROS analysis. $\mathrm{Al}^{3+}$ induced a significant increase in ROS in both cell populations (Figure 5), indicating $\mathrm{Al}^{3+}$ stimulates oxidative stress in yeast cells. The number of empty vector fluorescent cells lacking $A \beta 42$ production increased from $14.6 \%$ to $22.2 \%(7.6 \%)$ when treated with $5 \mathrm{mM} \mathrm{Al}^{3+}$ (Figure 5). Whereas the number of fluorescent cells producing $\mathrm{A} \beta 42$ increased from $17.1 \%$ to $32.2 \%$ (15.1\%) when treated with $5 \mathrm{mM} \mathrm{Al}^{3+}$ (Figure 5). $\mathrm{Al}^{3+}$ induced approximately double the amount of ROS-positive yeast cells expressing $A \beta 42$ as compared to the empty vector control. 


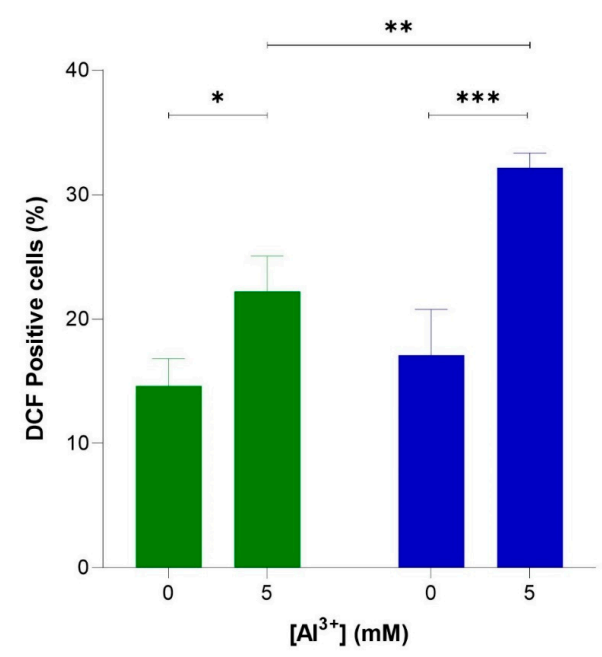

Figure 5. $\mathrm{Al}^{3+}$ induced reactive oxygen species (ROS) generation in S. cerevisiae BY4743 [pYEX.A $\beta$ ] (blue bar) and BY4743 [pYEX.BX] (green bar) using 2,7-dichlorodihydrofluorescein diacetate $\left(\mathrm{H}_{2} \mathrm{DCFDA}\right)$ staining. Values of dichlorofluorescein (DCF)-positive cell counts after $5 \mathrm{mM} \mathrm{Al}^{3+}$ treatment are from triplicates; the mean and standard deviation are shown. Values significantly different from $0 \mathrm{mM} \mathrm{Al}^{3+}$ and between the two transformant strains in a two-way ANOVA with Tukey's post hoc analysis are indicated with asterisks: ${ }^{*} p<0.0312,{ }^{* *} p<0.0074,{ }^{* * *} p<0.0005$.

\subsection{Glutathione Alleviates $A l^{3+}$ - and $A \beta_{42}$-Enhanced Induction of ROS}

To determine whether reduced glutathione could rescue ROS induced by $\mathrm{Al}^{3+}$ and enhanced by $\mathrm{A} \beta 42$, equimolar $(5 \mathrm{mM})$ glutathione $(\mathrm{GSH})$ was included in intracellular ROS analysis. Yeast cells expressing A $\beta 42$ were treated with $5 \mathrm{mM} \mathrm{GSH}$ and $5 \mathrm{mM} \mathrm{Al} \mathrm{m}^{3+}$, and the percentage of DCF-positive cells was compared with that of those treated with $5 \mathrm{mM} \mathrm{Al}^{3+}$ alone. The ROS induced by $\mathrm{Al}^{3+}$ was almost fully reduced by GSH (Figure 6). $\mathrm{Al}^{3+}$-treated BY4743 [pYEX.A $\beta$ ] DCF-positive cells reduced from $32.2 \%$ to $17.9 \%$ (reduction of $14.2 \%$ ) and brought the levels of ROS back down to nearly the initial percentage of DCF-positive $(17.1 \%)$ cells of the $\mathrm{Al}^{3+}$-untreated control population.

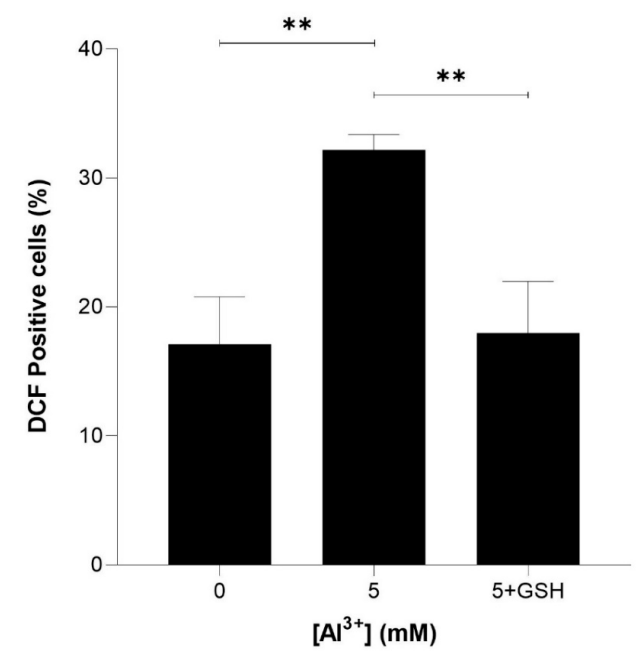

Figure 6. Glutathione (GSH) rescue of $\mathrm{Al}^{3+}$-induced ROS generation in S. cerevisiae BY4743 [pYEX.A $\beta$ ] using 2,7-dichlorodihydrofluorescein diacetate $\left(\mathrm{H}_{2} \mathrm{DCFDA}\right)$ staining. Bars represent dichlorofluorescein (DCF)-positive cell counts after $5 \mathrm{mM} \mathrm{Al}^{3+}$ treatment, $5 \mathrm{mM}$ GSH was used to rescue cells from oxidative stress caused by treatment with $5 \mathrm{mM} \mathrm{Al}^{3+}$ and the presence of $\mathrm{A} \beta_{42}$. Values are from triplicates; the mean and standard deviation are shown. Values significantly different from $0 \mathrm{mM}$, $5 \mathrm{mM} \mathrm{Al}^{3+}$ and GSH rescue in a one-way ANOVA with Tukey's post hoc analysis are indicated with asterisks: ${ }^{* *} p<0.0040$. 


\section{Discussion}

$\mathrm{Al}^{3+}$ cytotoxicity was tested for its ability to reduce cell viability and cause growth inhibition in yeast expressing GFP and GFP fused to $A \beta 42$. The cytotoxicity, reduction in cell viability, and growth inhibition caused by $\mathrm{Al}^{3+}$ and enhanced by $\mathrm{A} \beta 42$ was found to be due to increased production of ROS leading to enhanced oxidative stress, a characteristic hallmark of AD.

Results of the toxic effects of $\mathrm{Al}^{3+}$ and $\mathrm{A} \beta 42$ seen are independently supported by several reports. $\mathrm{Al}^{3+}$ is a known pro-oxidant and has been shown to exacerbate oxidative events [1,24-26] resulting in apoptosis, which is thought to be the general mechanism of $\mathrm{Al}^{3+}$ toxicity towards cells [27]. Mammalian studies of cortical and hippocampal neurons treated with $A \beta 42$ indicated that $A \beta 42$ induced the degeneration and death of cells via apoptosis [28]. These results have been further supported in studies demonstrating that treating mammalian cells with $\mathrm{Al}^{3+}$ enhances cell death in a time- and dose-dependent manner, exhibiting characteristic features of apoptosis such as shrinkage of cell bodies and hypercondensed, irregularly shaped chromatin [29]. $\mathrm{Al}^{3+}$ has also been shown to induce the degeneration of human astrocytes via apoptosis resulting in neuronal death [30]. Further, the toxic synergy of $\mathrm{A} \beta 42$ and $\mathrm{Al}^{3+}$ observed in the current study is supported by studies that demonstrated $A \beta 42$ conjugated with $\mathrm{Al}^{3+}$ significantly disrupted $\mathrm{Ca}^{2+}$ homeostasis and affected mitochondrial respiration to a greater extent than $\mathrm{A} \beta 42$ alone or when it was conjugated with other metal ions [31,32].

A recent study assessed $\mathrm{Al}^{3+}$ toxicity towards human neuroblastoma, SH-SY5Y cells, and showed a time- and concentration-dependent effect. Concentrations of 500 and 300 $\mu \mathrm{m}$ severely inhibited growth proliferation when exposed to $\mathrm{Al}^{3+}$ for 48 and $72 \mathrm{~h}$, respectively [33]. $\mathrm{Al}^{3+}$ was demonstrated to induce cellular stress response due to elevated ROS. Additionally, the levels of $\mathrm{A} \beta 42$ in SH-SY5Y cells treated with $\mathrm{Al}^{3+}$ were found to be higher in cells exposed to $\mathrm{Al}^{3+}$ treatment [33], suggesting $\mathrm{Al}^{3+}$ affects $\mathrm{A} \beta$ generation. Other recent studies provide evidence that $A l^{3+}$ can alter $A \beta$ structure and $\beta$ sheet structure content, implying $\mathrm{Al}^{3+}$ facilitates the aggregation of $\mathrm{A} \beta$ peptides [9]. Elevated levels of soluble and insoluble $A \beta 40$ and $A \beta 42$ in mice cortex and hippocampus regions due to $\mathrm{Al}^{3+}$ treatment have also been observed [26]. Further studies have demonstrated A $\beta 42$ induces significant apoptosis in mouse cerebral cortical neurons via targeting mitochondria, in the form of membrane potential disruption and increased intracellular ROS levels [34]. Thus, results from previous studies and the current study imply that cell death observed is via apoptosis, likely caused by $\mathrm{Al}^{3+}$ induction of ROS, leading to an elevated oxidative stress response, which is enhanced by the presence of $A \beta 42$. The enhanced cell death caused by the presence of $A \beta 42$ was expected, as yeast constitutively expressing native $A \beta 42$ have previously been shown to result in a lower cell growth rate, biomass yield, respiratory rate, proteasomal activity, and increased oxidative stress [35].

The studies discussed above primarily focused on $\mathrm{Al}^{3+}$ and $\mathrm{A} \beta 42$ cytotoxicity towards cells and their effects on oxidative stress as independent factors. The current study provides a robust link that the cytotoxicity of $\mathrm{Al}^{3+}$ is enhanced by $\mathrm{A} \beta 42$. Further, results from the growth inhibition assay provide an additional line of evidence that the difference in cytotoxicity and growth inhibition seen at $6.4 \mathrm{mM}$ between yeast cells expressing GFP alone and those producing GFP-A $\beta 42$ (Figure 3 ) is due to a combined toxic effect of $\mathrm{Al}^{3+}$ and $A \beta 42$, resulting in the programmed death of cells. However, the present study is not without its limitations. While high levels of $\mathrm{Al}^{3+}$ were required to observe $\mathrm{Al}^{3+}$ toxicity in yeast, much higher than those observed in human brains [20-23], it may be important to measure how much $\mathrm{Al}^{3+}$ was taken up by the yeast. Furthermore, besides $\mathrm{A} \beta$, the hyperphosphorylation of tau and the formation of neurofibrillary tangles (NFTs) represents the other major characteristic hallmark of $\mathrm{AD}$ progression. Assessment of $\mathrm{Al}^{3+}$ impact on tau biology and toxicity towards yeast cells could not be achieved using the current yeast model system. This provides further research opportunities to assess $\mathrm{Al}^{3+}$ impact on tau biology in yeast model systems or human in vitro systems expressing tau. This approach 
may provide insights into a potential toxic interaction between $\mathrm{Al}^{3+}$ and tau, which may lead to disease progression and neuronal loss.

Despite this, the combination of results obtained from cell viability/cytotoxicity measurements and the growth inhibition assays demonstrate a cytotoxic effect of $\mathrm{Al}^{3+}$ and $A \beta 42$ on yeast cells, suggesting a detrimental synergy between these two AD-linked factors.

In this study, $\mathrm{Fe}^{3+}$ increased $\mathrm{Al}^{3+}$ toxicity and $\mathrm{Al}^{3+}-\mathrm{A} \beta_{42}$ toxic synergy. The cytotoxicity and growth inhibitory effects of $\mathrm{Al}^{3+}$ and $\mathrm{Fe}^{3+}$ seen in this study are likely due to elevated ROS and exacerbated oxidative damage. Iron and the dysregulation of its homeostasis has previously been implicated in $\mathrm{Al}^{3+}$ toxicity and in the aetiology of $\mathrm{AD}[1,2,4,36]$. $\mathrm{Al}^{3+}$ binds to several metal-binding proteins and affects metal homeostasis [2]. Additionally, free iron is believed to be a moderator of oxidation in cellular systems due to its capacity to produce ROS via Fenton chemistry [1]. In contrast to iron, aluminium is redox inert, and its ability to induce oxidative stress is thought to be related to a synergistic mechanism that involves iron [1]. This implies intracellular $\mathrm{Fe}^{3+}$ in yeast may be playing a role in the elevated ROS seen in yeast cells treated with $\mathrm{Al}^{3+}$ in the present study. $\mathrm{Al}^{3+}$ has been shown to elicit Fe-induced membrane lipid peroxidation resulting in oxidative damage in vitro and in vivo, whereas $\mathrm{Al}^{3+}$ alone appears unable to directly impact lipid peroxidation $[2,37,38]$. Iron-induced oxidative stress has been shown to damage proteins and lipids, stimulate apoptotic signalling pathways in neurons, induce synaptic dysfunction, and cause neuronal cell death [39]. A synergistic effect of $\mathrm{Al}^{3+}$ and $\mathrm{Fe}^{3+}$ in human neural cells induced pro-inflammatory and pro-apoptotic genes [40].

$\mathrm{Al}^{3+}$ and $\mathrm{Fe}^{3+}$ have also been suggested to interact with $\mathrm{A} \beta$, induce expression of amyloid precursor protein, and enhance $A \beta$ accumulation $[2,41]$. Thus, under these conditions, $A D$ patients may accumulate more intracellular $A \beta$, which could result in additional damage. Further, evidence suggests that amyloid plaques can act as reservoirs for $\mathrm{Al}^{3+}$ and $\mathrm{Fe}^{3+}$, and $\mathrm{A} \beta 42$ can impact Fenton chemistry via the aggregation-state-specific binding of $\mathrm{Fe}^{3+}$ [42]. Furthermore, $\mathrm{Fe}^{3+}$ high affinity for binding with $\mathrm{A} \beta$ in vitro, may promote the aggregation of peptides and accelerate the formation of oligomers and increase cytotoxicity $[4,43,44]$. In addition, studies in Drosophila models suggest $\mathrm{Fe}^{3+}$ only enhances $A \beta$ toxicity if the metal is present throughout the $A \beta$ aggregation process [43]. Thus, the slight difference in growth between yeast cells producing GFP and those producing GFP-A $\beta 42$ in Figure 4 may be due to enhanced oxidative stress, caused by a combination of $\mathrm{Al}^{3+}, \mathrm{Fe}^{3+}$, and $\mathrm{A} \beta 42$ or $\mathrm{Fe}^{3+\prime}$ s impact on the $\mathrm{A} \beta 42$ aggregation state.

Iron levels rise in the brain because of ageing $[4,36]$. Thus, in conclusion, results obtained from the current study provide evidence that age-related factors such as $\mathrm{Fe}^{3+}$ and $\mathrm{Al}^{3+}$ facilitate damage that impacts $\mathrm{A} \beta 42$ aggregation and deposition and are likely to play key roles in oxidative stress and toxicity in regions of the brain affected in AD. Further investigation of iron and its interaction with $\mathrm{Al}^{3+}$ will be highly valuable in understanding how these metals impact $\mathrm{AD}$ and in what way they contribute to the aetiology of the disease.

Thus, $\mathrm{A} \beta 42$ and $\mathrm{Al}^{3+}$ combined toxicity could be lethal to human neuronal cells and is likely to contribute to the progression of $\mathrm{AD}$ and may represent an early event in $\mathrm{AD}$-affected brains. To further support these claims and to determine whether $\mathrm{Al}^{3+}$ and A $\beta 42$ synergistic toxicity was causing loss of yeast cell viability and growth inhibition via increased oxidative stress and apoptosis, intracellular ROS levels of yeast producing native $\mathrm{A} \beta 42$ were quantified, and the potential reduction of elevated ROS by GSH was examined.

Results from ROS analysis strongly support the $\mathrm{Al}^{3+}$ and $\mathrm{A} \beta 42$ synergistically stimulated ROS production, leading to increased oxidative stress in yeast cells, which may be resulting in the initiation of programmed cell death. Evidence suggests the generation of ROS is one of the initial factors contributing to the development of $\mathrm{AD}[14,45,46]$. A $\beta 42$ and its interplay with mitochondrial dysfunction, energy metabolism, and oxidative stress exacerbates the progression of AD and represents an early event in AD-affected brains [47]. Results obtained in the current study imply ROS generation may be due not only to increased deposition of $\mathrm{A} \beta 42$ but could also be a result of early and ongoing exposure to $\mathrm{Al}^{3+}$ 
and their combined ability to enhance ROS generation via a co-active toxic synergy. Further, the enhanced generation of ROS may be affecting mitochondrial respiratory function and damaging mitochondrial DNA, consequently having a severe impact on cells through the initiation of cell death.

$\mathrm{Al}^{3+}$ has previously been implicated in the alteration of glutathione levels in rat brains $[48,49]$. Rats exposed to $\mathrm{Al}^{3+}$ for a prolonged period exhibited a significant decrease in total glutathione, GSH, and oxidized glutathione content in the cerebrum, cerebellum, medulla oblongata, and the hypothalamus regions of the brain [49]. $\mathrm{Al}^{3+}$ also caused a significant reduction in glutathione reductase activity. Time-dependent effects of $\mathrm{Al}^{3+}$ on glutathione levels in human whole blood have also been examined, with $\mathrm{Al}^{3+}$ causing a decrease in GSH [50]. In addition, $\mathrm{Al}^{3+}$ has previously been shown to activate monoamine oxidase (MAO) activity and subsequent ROS production [48,51,52]. Although, yeast do not possess monoamine oxidases (types A and B), they have orthologs of MAO A and B, known as polyamine oxidase, which may impact $\mathrm{Al}^{3+}$ induction of elevated ROS levels in yeast cells. This phenomenon further supports the involvement of $\mathrm{ROS}$ in $\mathrm{Al}^{3+}$-mediated toxicity, which could be due to $\mathrm{Al}^{3+\text { 's }}$ interaction with $\mathrm{A} \beta 42$. Thus, results from the present study suggest $\mathrm{Al}^{3+}$ may be inducing the production of reaction products such as hydrogen peroxide and reducing intracellular GSH.

Increased hydrogen peroxide may also be available for iron-mediated Fenton reactions to generate highly reactive hydroxyl radicals, enhancing oxidative damage towards mitochondria. The alteration of iron's homoeostatic levels in the brain can independently cause ROS formation as discussed. Further, A $\beta 42$ could be contributing to the generation of ROS at the mitochondrial electron transport chain. These mechanisms are apt to result in increased oxidative stress and damage to mitochondria. Recovery of yeast producing A $\beta 42$ from ROS generation with exogenously added GSH effectively supports these claims and findings.

It is clear severe oxidative damage caused by a coaction of $\mathrm{Al}^{3+}$ and $\mathrm{A} \beta 42$ is toxic towards cells, ultimately leading to cellular death. Further research could incorporate ROS analysis of yeast cells expressing $A \beta 42$ that have been treated with $\mathrm{Al}^{3+}$ alongside investigation of these toxic mechanisms on yeast mitochondria. Additional examination will assist in providing further evidence that the combined oxidative damaging effect of $\mathrm{Al}^{3+}$ and $\mathrm{A} \beta 42$ is in fact via elevated ROS generation possibly on mitochondrial enzymes, and to the mitochondrial genome itself. In humans, the toxic co-action of $\mathrm{Al}^{3+}$ and $\mathrm{A} \beta 42$ could cause severe mitochondrial dysfunction and be lethal to neuronal cells, which would likely play a substantial role in the early neural degenerative process of AD.

In summary, this study provides multiple lines of evidence that suggest and support $\mathrm{Al}^{3+\prime}$ s probable involvement in $\mathrm{AD}$. Further, it provides evidence that $\mathrm{Al}^{3+\prime}$ s involvement in the development and cause of AD could be via a toxic synergy with $A \beta_{42}$, which may lead to neuronal cell death. $\mathrm{Al}^{3+}$-induced neurodegeneration appears to be associated with several cellular and molecular pathways that are both dependent and independent of $\mathrm{A} \beta_{42}$-associated toxicity, which is linked to $\mathrm{Fe}^{3+}$ levels and oxidative stress in the brain. Furthermore, aluminium's ubiquitous presence in human lives is of great importance, as $\mathrm{Al}^{3+}$ can cross the BBB. Results of the current study provide crucial evidence and reasoning to consider minimizing our exposure to $\mathrm{Al}^{3+}$ as a preventative measure against AD. Additionally, it demonstrates the advantages of using yeast as a model organism for studying $\mathrm{Al}^{3+}$ toxicity and its involvement in $\mathrm{AD}$ and for rapid experimentation. Furthermore, it affords new opportunities to investigate therapeutics that may alleviate $\mathrm{Al}^{3+}$-induced toxicity and factors that affect the neurotoxin's harmfulness in yeast.

\section{Materials and Methods}

\subsection{Yeast Strains, Plasmids, and Growth Media}

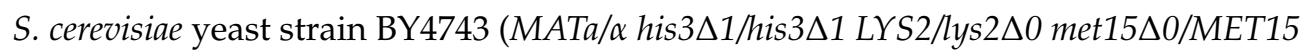
ura $3 \Delta 0 /$ ura $3 \Delta 0$ leu $2 \Delta 0 /$ leu $2 \Delta 0$ ) was the host strain used in this study. The plasmids p416GPD.GFPA $\beta$, p416GPD.GFP, pYEX.A $\beta$, and pYEX.BX were transformed into the 
host strain as previously described in $[17,19]$. Briefly, isolated colonies of S. cerevisiae BY4743 with a diameter of 3-4 mm were grown on YEPD and transformed using an EZ transformation kit. The $A \beta$ used in this study is the full-length peptide, composed of 42 amino acids (A $\beta 42)$.

Minimal selective media, composed of yeast nitrogen base without amino acids $(0.67 \%)$, dextrose $(2 \%)$, and agar $(2 \%)$, were used for the growth and selection of transformants. Supplementation of auxotrophic requirements was achieved by adding leucine $(20 \mathrm{mg} / \mathrm{L})$, histidine $(20 \mathrm{mg} / \mathrm{L})$, and uracil $(20 \mathrm{mg} / \mathrm{L})$, where required. Empty vector transformations and a negative control were also used to validate transformations. For long-term storage, yeast strains were stored at $-80{ }^{\circ} \mathrm{C}$ in minimal selective media with $15 \%$ $\mathrm{w} / \mathrm{v}$ glycerol. Low-pH and low-phosphate (LPP) medium supplemented with varying concentrations of aluminium sulphate $(\mathrm{Al} 2(\mathrm{SO} 4) 3)$, ferric chloride $(\mathrm{FeCl} 3)$, and reduced glutathione (GSH) were used for growth inhibition assays and ROS analysis, respectively. LPP consists of standard synthetic dextrose medium [53] with $4.9 \mathrm{mM} \mathrm{KCl}$ and $100 \mu \mathrm{M}$ of $\mathrm{KH} 2 \mathrm{PO} 4$ instead of $\mathrm{K} 2 \mathrm{HPO} 4$, and $\mathrm{pH}$ adjusted to 3.5 with $\mathrm{HCl}$ [24]. A low-pH media was used to promote and maintain $\mathrm{Al}^{3+}$ and $\mathrm{Fe}^{3+}$ solubility in medium, LPP was also supplemented with histidine and leucine where required. All assays were paired with a $\mathrm{HCl}$-positive control to see if addition of $\mathrm{HCl}$ affected cell growth.

Minimal selective, YEPD and YEPE media were used for yeast viability measurements. YEPD medium was composed of yeast extract $(1 \%)$, dextrose $(2 \%)$, peptone $(2 \%)$, and agar $(2 \%)$. YEPE medium consisted of the same components as YEPD, however, ethanol was used as the carbon source instead of dextrose. The addition of ethanol instead of dextrose enabled the effects of $\mathrm{Al}^{3+}$ and $\mathrm{A} \beta 42$ on respiratory growth to be assessed. All media materials were purchased from Sigma Aldrich.

$\mathrm{Al} 2(\mathrm{SO} 4) 3, \mathrm{FeCl} 3$, and GSH were supplied by Sigma Aldrich. Solutions of each compound were prepared using deionized water from a Milli-Q system. Al2(SO4)3 was freshly prepared as a $1 \mathrm{M}$ stock solution, $\mathrm{FeCl} 3$ was prepared as a $500 \mathrm{mM}$ stock, and GSH was prepared as a $500 \mathrm{mM}$ stock. All stock solutions were filter sterilized using a $2 \mu \mathrm{m}$ filter membrane.

\subsection{Yeast Viability Measurements}

For viability measurements, yeast cells of each transformant BY4743 [p416GPD.GFPA $\beta$ ] and BY4743 [p416GPD.GFP] in the log phase of growth were obtained from fresh cultures grown on minimal selective media supplemented with leucine and histidine. Cell numbers of each transformant were counted using a Neubauer counting chamber. Cells of each transformant were diluted accordingly and suspended at a density of $5 \times 10^{3}$ cells $/ \mathrm{mL}$ into a 24-well microplate containing sterile Milli-Q water and varying concentrations $(0,0.4,0.8$, $1.6,3.2,4.8,5.0$, and $10 \mathrm{mM})$ of $\mathrm{Al} 2(\mathrm{SO} 4) 3$. The choice of $\mathrm{Al}^{3+}$ treatment concentrations was based off previous $\mathrm{Al}^{3+}$ toxicity data on $\mathrm{S}$. cerevisiae [25] and covers a broad spectrum from benign to lethal doses. The concentrations of $\mathrm{Al}^{3+}$ treatment used are greater than amounts seen in human brains [20-23]: our study has not determined the levels of aluminium taken up by yeast. After exposure to $\mathrm{Al}^{3+}$ treatment for $24 \mathrm{~h}, 100 \mu \mathrm{L}$ aliquots of cell suspensions were plated onto solidified YEPD and YEPE plates. YEPE plates were also included to examine $\mathrm{Al}^{3+}$ s effect on respiratory growth and the possible induction of petites. Plates were incubated for 3-4 days at $30^{\circ} \mathrm{C}$, the number of colony-forming units of each strain was determined. All tests were performed in triplicate.

\subsection{Growth Inhibition Assays}

$\mathrm{Al} 2(\mathrm{SO} 4) 3$ was added to LPP medium at varying concentrations $(0,0.4,0.8,1.6,3.2$, 4.8 , and $6.4 \mathrm{mM}$ ) before on pouring plates and covers a broad spectrum from benign to lethal doses. As aforementioned, these concentrations are greater than physiologically relevant concentrations. Transformants freshly grown in yeast nitrogen base (YNB) minimal selective media supplemented with histidine and leucine were centrifuged and washed twice with Milli-Q water. Transformants were then separately aliquoted into a 96-well 
microtiter plate and were 10-fold serially diluted. Diluted cells were then inoculated onto fresh LPP plates supplemented with different concentrations of $\mathrm{Al}^{3+}$ using a multipronged inoculator. Cells were incubated at $30^{\circ} \mathrm{C}$ for 3-7 days. Growth inhibition in LPP plates was photographed using BIORAD ChemiDoc MP Imaging system, measured, scored, and analysed for differences between $\mathrm{Al}^{3+}$ treatment concentrations and cells producing GFP alone and those producing GFP-A $\beta$. A second growth inhibition assay following the same procedure described above was performed with the addition of $2 \mathrm{mM}$ of $\mathrm{FeCl} 3$ to plates containing $0,1.6,3.2$, and $4.8 \mathrm{mM} \mathrm{Al} 2(\mathrm{SO} 4) 3$, to analyse the effects of iron on $\mathrm{Al}^{3+}$ toxicity. Briefly, $2 \mathrm{mM} \mathrm{FeCl} 3$ was added to plates after pouring and solidification of LPP medium.

\subsection{Aluminium-Induced-ROS Detection in Yeast}

Intracellular ROS levels of yeast cells treated with varying concentrations of Al2(SO4)3 were determined by staining with $2^{\prime}, 7^{\prime}$-dichlorodihydrofluorescein diacetate (H2DCF-DA) and flow cytometric analysis as previously described in [19]. The presence of ROS is determined by the conversion of H2DCF-DA to DCF. Briefly, overnight cultures of BY4743 [pYEX.A $\beta$ ] and BY4743 [pYEX.BX] in YNB media supplemented with histidine were grown for $2-3 \mathrm{~h}$ at $30^{\circ} \mathrm{C}$ while shaking. Once cells reached the exponential growth phase, cells of each strain were centrifuged and washed twice with Milli-Q water, counted, and transferred to a 24 -well cell culture plate at a cell density of $10^{6}$ cells / mL containing LPP media supplemented with histidine. Cells were then treated with $5 \mathrm{mM} \mathrm{Al}^{3+}$ and incubated for $2 \mathrm{~h}$ at $30{ }^{\circ} \mathrm{C}$ while shaking. Cells were then centrifuged, washed twice with Mill-Q water, and re-suspended in YNB media supplemented with histidine. H2DCF-DA was added separately to both strains at a final concentration of $10 \mu \mathrm{g} / \mathrm{mL}$ during treatment. To ascertain whether reduced glutathione could reduce ROS generated by $\mathrm{Al}^{3+}, 5 \mathrm{mM}$ GSH was also added to $\mathrm{A} \beta 42$ cells treated with $5 \mathrm{mM} \mathrm{Al}^{3+}$ containing H2DCF-DA. Cells were then incubated in the dark at $30{ }^{\circ} \mathrm{C}$ for $2 \mathrm{~h}$ while shaking. After incubation, cells of each strain were collected and washed twice in sterile Milli-Q water. Cells were then incubated in YNB supplemented with histidine for $1 \mathrm{~h}$ to induce further growth. After final incubation, cells were washed with phosphate- buffered saline (PBS) and analysed for green fluorescence; all treatments were analysed in triplicates. DCF fluoresces at $530 \mathrm{~nm}$ when excited at $488 \mathrm{~nm}$; thus, green fluorescence emitted by blue laser at $488 \mathrm{~nm}$ was measured using a FACS Canto II flow cytometer (BD Life Sciences, San Jose, CA, USA) (10,000 events per sample). Controls comprised unstained cells of BY4743 [pYEX.A $\beta$ ] and BY4743 [pYEX.BX], untreated cells of each transformant strain, and a positive hydrogen peroxide control of BY4743 [pYEX.BX] to configure the gating strategy. Data output from flow cytometric analysis was analysed using Flow Jo Version 10.6.0 (BD Life Sciences, San Jose, CA, USA).

\subsection{Statistical Analysis}

Yeast viability measurements and intracellular ROS measurements data were obtained in triplicates and analysed using GraphPad Prism Version 8.4.3. Error bars represent the standard error of the mean (SEM). Significant differences between strains and treatments were compared using either a one-way or two-way ANOVA with Tukey's post hoc analysis.

\section{Conclusions}

Mounting evidence suggests exposure to aluminium, the most plentiful neurotoxic metal on the planet, may be a risk factor alongside other aetiological factors in the development of AD. The current study provides several lines of evidence of why $\mathrm{Al}^{3+}$ should be considered an important player in $\mathrm{AD}$. $\mathrm{Al}^{3+}$ significantly reduced cell viability, inhibited growth, and increased intracellular ROS in yeast cells. The effects of $\mathrm{Al}^{3+}$ on these three measures was significantly enhanced by the presence of $\mathrm{A} \beta 42$. This toxicity between $\mathrm{Al}^{3+}$ and $A \beta 42$ was observed to be detrimental to yeast cells via increased oxidative stress. Additionally, $\mathrm{Fe}^{3+}$ was found to enhance the growth inhibitory effects of $\mathrm{Al}^{3+}$ and $\mathrm{A} \beta 42$ combined toxicity. This link between $\mathrm{Al}^{3+}$ and $\mathrm{A} \beta 42$ may be an important aetiological 
factor in the early and late development of $\mathrm{AD}$. Thus, the toxic synergy between $\mathrm{Al}^{3+}$ and $\mathrm{A} \beta 42$ should not be ignored.

This work also validates the efficacy of yeast as a model to study AD and, in particular, toxic agents that might exacerbate AD pathology. However, the yeast model is not without its limitations: yeast lack specific processes of neuronal cells, a nervous system, and neuropathology associated with cell-cell communications. Thus, validation of significant findings in more complex mammalian models and human in vitro systems is necessary. Additionally, the model system used in the present study does not provide insights into $\mathrm{Al}^{3+}$ 's impact on tau and the formation of NFTs, which represents the other major characteristic hallmark of AD. This provides further research opportunities, which could yield important insights into $\mathrm{Al}^{3+}$ involvement in the progression of $\mathrm{AD}$. Despite this, the current study provides additional opportunities to further use the yeast model system to screen chemical compounds that may alleviate or intervene with the synergistic toxicity of $\mathrm{Al}^{3+}$ and $\mathrm{A} \beta 42$. The most effective compounds will be those that simultaneously target $\mathrm{Al}^{3+}$, elevated $\mathrm{Fe}^{3+}$, and $A \beta 42$ in the brain. Exploring multitarget therapeutics that have the capacity to reverse $\mathrm{A} \beta 42$ aggregation, dissolve amyloid plaques, and remove $\mathrm{Al}^{3+}$ from the brain to restore and maintain brain metal ion homeostasis and ultimately prevent $\mathrm{AD}$-associated cognitive damage will be extremely valuable.

Author Contributions: J.B.M. conceived, designed, and wrote the paper. S.D. co-drafted and revised the paper. I.M. conceived and supervised the paper. All authors have read and agreed to the published version of the manuscript.

Funding: This research received no external funding.

Institutional Review Board Statement: Not Applicable.

Informed Consent Statement: Not applicable.

Data Availability Statement: Not Applicable.

Conflicts of Interest: The authors declare no conflict of interest.

\section{Abbreviations}

$\begin{array}{ll}\mathrm{AD} & \text { Alzheimer's disease } \\ \mathrm{A} \beta & \text { Amyloid beta } \\ \mathrm{GFP} & \text { Green fluorescent protein } \\ \mathrm{Al}^{3+} & \text { Aluminium ion } \\ \mathrm{ROS} & \text { Reactive oxygen species } \\ \mathrm{GFP}-\mathrm{A} \beta 42 & \text { Green fluorescent protein tagged with amyloid beta } 42 \\ \mathrm{Fe}^{3+} & \text { Ferric ion } \\ \mathrm{Fe}^{2+} & \text { Ferrous ion } \\ \mathrm{H}_{2} \mathrm{DCFDA} & 2^{\prime}, 7^{\prime} \text {-dichlorodihydrofluorescein diacetate } \\ \mathrm{DCF} & \text { Dichlorofluorescein } \\ \mathrm{GSH} & \text { Glutathione } \\ \text { YEPD } & \text { Yeast extract peptone dextrose } \\ \text { YEPE } & \text { Yeast extract peptone ethanol } \\ \text { YNB } & \text { Yeast nitrogen base } \\ \mathrm{MAO} & \text { Monoamine oxidase } \\ \text { LPP } & \text { Low } \mathrm{pH} \text { and low phosphate }\end{array}$

\section{References}

1. Tomljenovic, L. Aluminum and Alzheimer's Disease: After a century of controversy, is there a plausible link? J. Alzheimer's Dis. 2011, 23, 567-598. [CrossRef]

2. Kawahara, M.; Kato-Negishi, M. Link between aluminum and the pathogenesis of Alzheimer's Disease: The integration of the aluminum and amyloid cascade hypotheses. Int. J. Alzheimer's 2011, 2011, 1-17. [CrossRef]

3. Rondeau, V.; Commenges, D.; Jacqmin-Gadda, H.; Dartigues, J-F. Relation between aluminum concentrations in drinking water and Alzheimer's Disease: An 8-year follow-up study. Am. J. Epidemiol. 2000, 152, 59-66. [CrossRef] [PubMed] 
4. Li, Y.; Jiao, Q.; Xu, H.; Du, X.; Shi, L.; Jia, F.; Jiang, H. Biometal dyshomeostasis and toxic metal accumulations in the development of Alzheimer's Disease. Front. Mol. Neurosci. 2017, 10, 339. [CrossRef]

5. Yokel, R.A. Blood-brain barrier flux of aluminum, manganese, iron and other metals suspected to contribute to metal-induced neurodegeneration. J. Alzheimer's Dis. 2006, 10, 223-253. [CrossRef]

6. Exley, C. Aluminum should now be considered a primary etiological factor in Alzheimer's Disease. J. Alzheimer's Dis. Rep. 2017, 1, 23-25. [CrossRef]

7. Lupaescu, A.-V.; Humelnicu, I.; Petre, B.A.; Ciobanu, C.-I.; Drochioiu, G. Direct evidence for binding of aluminum to NAP anti-amyloid peptide and its analogs. Eur. J. Mass Spectrom. 2020, 26, 106-116. [CrossRef] [PubMed]

8. Mold, M.; Linhart, C.; Gómez-Ramírez, J.; Villegas-Lanau, A.; Exley, C. Aluminum and amyloid- $\beta$ in familial Alzheimer's Disease. J. Alzheimer's Dis. 2020, 73, 1627-1635. [CrossRef]

9. Zhang, Q.; Zhang, F.; Ni, Y.; Kokot, S. Effects of aluminum on amyloid-beta aggregation in the context of Alzheimer's disease. Arab. J. Chem. 2019, 12, 2897-2904. [CrossRef]

10. Selkoe, D.J.; Hardy, J. The amyloid hypothesis of Alzheimer's disease at 25 years. EMBO Mol. Med. 2016, 8, 595-608. [CrossRef]

11. Sharma, P.; Srivastava, P.; Seth, A.; Tripathi, P.N.; Banerjee, A.G.; Shrivastava, S.K. Comprehensive review of mechanisms of pathogenesis involved in Alzheimer's disease and potential therapeutic strategies. Prog. Neurobiol. 2019, 174, 53-89. [CrossRef] [PubMed]

12. Sengupta, U.; Nilson, A.N.; Kayed, R. The role of amyloid- $\beta$ oligomers in toxicity, propagation, and immunotherapy. EBioMedicine 2016, 6, 42-49. [CrossRef]

13. Seynnaeve, D.; Vecchio, M.; Fruhmann, G.; Verelst, J.; Cools, M.; Beckers, J.; Mulvihill, D.P.; Winderickx, J.; Franssens, V. Recent insights on Alzheimer's Disease originating from yeast models. Int. J. Mol. Sci. 2018, 19, 1947. [CrossRef] [PubMed]

14. Tönnies, E.; Trushina, E. Oxidative stress, synaptic dysfunction, and Alzheimer's Disease. J. Alzheimer's Dis. 2017, 57, 1105-1121. [CrossRef] [PubMed]

15. Mcdonald, J.B.; Dhakal, S.; Macreadie, I.G. Yeast contributions to Alzheimer's Disease. J. Hum. Clin. Gen. 2020, 2, 1-19. [CrossRef]

16. Dhakal, S.; Macreadie, I. Protein homeostasis networks and the use of yeast to guide interventions in Alzheimer's Disease. Int. J. Mol. Sci. 2020, 21, 8014. [CrossRef]

17. Porzoor, A.; Macreadie, I. Yeast as a model for studies on A $\beta$ aggregation toxicity in Alzheimer's Disease, autophagic responses, and drug screening. In Systems Biology of Alzheimer's Disease; Castrillo, J.I., Oliver, S.G., Eds.; Springer: New York, NY, USA, 2016; pp. 217-226.

18. Dhakal, S.; Subhan, M.; Fraser, J.M.; Gardiner, K.; Macreadie, I. Simvastatin efficiently reduces levels of Alzheimer's amyloid beta in yeast. Int. J. Mol. Sci. 2019, 20, 3531. [CrossRef] [PubMed]

19. Dhakal, S.; Macreadie, I. Tyramine and amyloid beta 42: A toxic synergy. Biomedicines 2020, 8, 145. [CrossRef]

20. Crapper, D.R.; Krishnan, S.S.; Dalton, A.J. Brain aluminum distribution in Alzheimer's Disease and experimental neurofibrillary degeneration. Science 1973, 180, 511-513. [CrossRef]

21. Perl, D.; Brody, A. Alzheimer's disease: X-ray spectrometric evidence of aluminum accumulation in neurofibrillary tangle-bearing neurons. Science 1980, 208, 297-299. [CrossRef]

22. Walton, J.R. Aluminum in hippocampal neurons from humans with Alzheimer's disease. Neurotoxicology 2006, $27,385-394$. [CrossRef] [PubMed]

23. Yumoto, S.; Kakimi, S.; Ohsaki, A.; Ishikawa, A. Demonstration of aluminum in amyloid fibers in the cores of senile plaques in the brains of patients with Alzheimer's disease. J. Inorg. Biochem. 2009, 103, 1579-1584. [CrossRef]

24. Yamamoto, T.; Yamamoto, D.; Rokugawa, K.; Yoshimura, K.; Imura, Y.; Yoshimura, E.; Suzuki, M. Decreased aluminium tolerance in the growth of Saccharomyces cerevisiae with SSO2 gene disruption. Biometals 2018, 31, 203-215. [CrossRef]

25. Tun, N.M.; O’Doherty, P.J.; Chen, Z.-H.; Wu, X.-Y.; Bailey, T.D.; Kersaitis, C.; Wu, M.J. Identification of aluminium transport-related genes via genome-wide phenotypic screening of Saccharomyces cerevisiae. Metallomics 2014, 6, 1558. [CrossRef]

26. Praticò, D.; Uryu, K.; Sung, S.; Tang, S.; Trojanowski, J.Q.; Lee, V.M.-Y. Aluminum modulates brain amyloidosis through oxidative stress in APP transgenic mice. FASEB J. 2002, 16, 1138-1140. [CrossRef]

27. Zheng, K.; Pan, J.-W.; Ye, L.; Fu, Y.; Peng, H.-Z.; Wan, B.-Y.; Gu, Q.; Bian, H.-W.; Han, N.; Wang, J.-H.; et al. Programmed cell death-involved aluminum toxicity in yeast alleviated by antiapoptotic members with decreased calcium signals. Plant Physiol. 2007, 143, 38-49. [CrossRef]

28. Loo, D.T.; Copani, A.; Pike, C.J.; Whittemore, E.R.; Walencewicz, A.J.; Cotman, C.W. Apoptosis is induced by beta-amyloid in cultured central nervous system neurons. Proc. Natl. Acad. Sci. USA 1993, 90, 7951-7955. [CrossRef] [PubMed]

29. Maya, S.; Prakash, T.; Madhu, K.D.; Goli, D. Multifaceted effects of aluminium in neurodegenerative diseases: A review. Biomed. Pharmacother. 2016, 83, 746-754. [CrossRef] [PubMed]

30. Suárez-Fernández, M.B.; Soldado, A.B.; Sanz-Medel, A.; Vega, J.-A.; Novelli, A.; Fernández-Sánchez, M.T. Aluminum-induced degeneration of astrocytes occurs via apoptosis and results in neuronal death. Brain Res. 1999, 835, 125-136. [CrossRef]

31. Drago, D.; Cavaliere, A.; Mascetra, N.; Ciavardelli, D.; Di Ilio, C.; Zatta, P.; Sensi, S.L. Aluminum modulates effects of $\beta$ Amyloid 1-42 on neuronal calcium homeostasis and mitochondria functioning and is altered in a triple transgenic mouse model of Alzheimer's Disease. Rejuvenation Res. 2008, 11, 861-871. [CrossRef] [PubMed]

32. Ricchelli, F.; Drago, D.; Filippi, B.; Tognon, G.; Zatta, P. Aluminum-triggered structural modifications and aggregation of $\beta$-amyloids. Cell. Mol. Life Sci. 2005, 62, 1724-1733. [CrossRef] [PubMed] 
33. Yang, M.H.; Chen, S.C.; Lin, Y.F.; Lee, Y.C.; Huang, M.Y.; Chen, K.C.; Wu, H.-Y.; Lin, P.C.; Gozes, I.; Tian, Y.C. Reduction of aluminum ion neurotoxicity through a small peptide application-NAP treatment of Alzheimer's disease. J. Food Drug Anal. 2019, 27, 551-564. [CrossRef] [PubMed]

34. Han, X.-J.; Hu, Y.-Y.; Yang, Z.-J.; Jiang, L.-P.; Shi, S.-L.; Li, Y.-R.; Guo, M.Y.; Wu, H.L.; Wan, Y.Y. Amyloid $\beta-42$ induces neuronal apoptosis by targeting mitochondria. Mol. Med. Rep. 2017, 16, 4521-4528. [CrossRef]

35. Chen, X.; Misschops, M.M.M.; Agarwal, N.R.; Ji, B.; Shanmugavel, K.P.; Petranovic, D. Interplay of energetics and ER stress exacerbates Alzheimer's amyloid- $\beta$ (A $\beta$ ) toxicity in yeast. Front. Mol. Neurosci. 2017, 10, 232. [CrossRef] [PubMed]

36. Ayton, S.; Lei, P.; Bush, A.I. Biometals and their therapeutic implications in Alzheimer's Disease. Neurotherapeutics 2015, 12, 109-120. [CrossRef] [PubMed]

37. Oteiza, P.I. A mechanism for the stimulatory effect of aluminum on iron-induced lipid peroxidation. Arch. Biochem. Biophys. 1994, 308, 374-379. [CrossRef]

38. Kaneko, N.; Sugioka, T.; Sakurai, H. Aluminum compounds enhance lipid peroxidation in liposomes: Insight into cellular damage caused by oxidative stress. J. Inorg. Biochem. 2007, 101, 967-975. [CrossRef] [PubMed]

39. Mattson, M.P. Metal-catalyzed disruption of membrane protein and lipid signaling in the pathogenesis of neurodegenerative disorders. Ann. N. Y. Acad. Sci. 2004, 1012, 37-50. [CrossRef]

40. Alexandrov, P.N.; Zhao, Y.; Pogue, A.I.; Tarr, M.A.; Kruck, T.P.A.; Percy, M.E.; Cui, J.G.; Lukiw, W.J. Synergistic effects of iron and aluminum on stress-related gene expression in primary human neural cells. J. Alzheimer's Dis. 2005, 8, 117-127. [CrossRef]

41. Ndayisaba, A.; Kaindlstorfer, C.; Wenning, G.K. Iron in neurodegeneration-Cause or consequence? Front. Neurosci. 2019, 13, 180. [CrossRef]

42. Khan, A.; Dobson, J.P.; Exley, C. Redox cycling of iron by A 342 . Free Radic. Biol. Med. 2006, 40, 557-569. [CrossRef]

43. Ott, S.; Dziadulewicz, N.; Crowther, D.C. Iron is a specific cofactor for distinct oxidation- and aggregation-dependent A toxicity mechanisms in a Drosophila model. Dis. Model Mech. 2015, 8, 657-667. [CrossRef]

44. Liu, J.L.; Fan, Y.G.; Yang, Z.S.; Wang, Z.-Y.; Guo, C. Iron and Alzheimer's Disease: From pathogenesis to therapeutic implications. Front. Neurosci. 2018, 12, 632. [CrossRef]

45. Coyle, J.; Puttfarcken, P. Oxidative stress, glutamate, and neurodegenerative disorders. Science 1993, 262, 689-695. [CrossRef] [PubMed]

46. Cheignon, C.; Tomas, M.; Bonnefont-Rousselot, D.; Faller, P.; Hureau, C.; Collin, F. Oxidative stress and the amyloid beta peptide in Alzheimer's disease. Redox Biol. 2018, 14, 450-464. [CrossRef] [PubMed]

47. Chen, X.; Petranovic, D. Amyloid- $\beta$ peptide-induced cytotoxicity and mitochondrial dysfunction in yeast. FEMS Yeast. Res. 2015, 15, fov061. [CrossRef]

48. De Marchi, U.; Mancon, M.; Battaglia, V.; Ceccon, S.; Cardellini, P.; Toninello, A. Influence of reactive oxygen species production by monoamine oxidase activity on aluminum-induced mitochondrial permeability transition. Cell. Mol. Life Sci. 2004, 61, 2664-2671. [CrossRef]

49. Nehru, B.; Bhalla, P. Reversal of an aluminium induced alteration in redox status in different regions of rat brain by administration of centrophenoxine. Mol. Cell. Biochem. 2006, 290, 185-191. [CrossRef] [PubMed]

50. Khan, H.; Khan, M.F.; Jan, S.U.; Ullah, N. Effect of aluminium metal on glutathione (GSH) level in plasma and cytosolic fraction of human blood. Pak. J. Pharm. Sci. 2011, 24, 13-18.

51. Rao, J.K.S.; Rao, G.V. Effect of aluminium (Al) on brain mitochondrial monoamine oxidase-A (MAO-A) activity? An in vitro kinetic study. Mol. Cell. Biochem. 1994, 137, 57-60. [PubMed]

52. Zatta, P.; Zambenedetti, P.; Milanese, M. Activation of monoamine oxidase type-B by aluminum in rat brain homogenate. NeuroReport 1999, 10, 3645-3648. [CrossRef] [PubMed]

53. Sherman, F. Getting started with yeast. Methods Enzymol. 2002, 350, 3-41. [PubMed] 